\title{
Spontaneous migration of a retained bullet within the brain: a case report
}

\author{
Beyin içinde kalan kurşunun kendiliğinden yer değiştirmesi: Olgu sunumu
}

\author{
Mehmet ARSLAN, Metehan ESEOĞLU, Burhan Oral GÜDÜ, İsmail DEMİR, Abdul Baki KOZAN
}

Gunshot injury to the head is usually mortal, and spontaneous migration of a retained bullet is rare. We report the case of a 23-year-old man with a spontaneously migrated bullet within the brain. Cranial computerized tomography (CT) indicated that the bullet was lodged deeply in the left parietal region. The patient was conscious and had right homonymous hemianopsia. The bullet was close to the vital structures and deep-seated; therefore, surgical intervention was not considered. Two months after the injury, repeat CT revealed that the bullet had migrated posteriorly and caudally due to gravitational factors. Management of the retained bullet was controversial. Removal of a deep-seated bullet may cause additional neurological deficit, but migration of a retained bullet may cause damage to vital structures, producing significant neurological damage. We proposed that the bullet in the brain should be removed if it could be reasonably accessed without causing additional neurological damage.

Key Words: Brain injury; bullet; spontaneous migration.
Başın kurşun yaralanmaları genellikle ölümcüldür ve beyin içinde kalan kurşunun kendiliğinden hareketi nadir bir durumdur. Bu olgu sunumunda, 23 yaşındaki erkek hastanın beyninde kendiliğinden hareket eden kurşun sunuldu. Beyin bilgisayarlı tomogafisi (BT) kurşunun sol parietal bölgede derin yerleşimli olduğunu gösterdi. Hastanın bilinci açıktı ve sağ homonium hemianopsi vard1. Kurşun, hayati yapılara yakın ve derin yerleşimliydi. Bu yüzden, cerrahi girişim düşünülmedi. İki ay sonra çekilen kontrol BT'sinde kurşunun yerçekimi etkisi ile kaudale ve posteriyora doğru yer değiştirdiği görüldü. Beyin içinde kalan kurşunun tedavisi tartışmalıdır. Derinde yerleşen kurşunu çıkarmak ek nörolojik hasara neden olabileceği gibi kalan kurşunun hareketi de hayati yapıların zarar görmesine neden olabilir.Sonuç olarak, ek nörolojik defisite neden olmayacak kolay ulaşılabilir kurşunların çıkarılmasını öneriyoruz.

Anahtar Sözcükler: Beyin yaralanması; kurşun; spontan hareket.
Gunshot head injuries are the most lethal types of the cranial traumas and they are usually mortal. The mortality rate has been reported as ranging from 51$84 \% .{ }^{[1]}$ The velocity, distance of flight, refraction, caliber, trajectory, bullet migration, brain damage degree, and vascular injury are the factors that affect mortality.

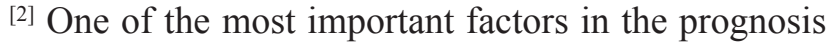
is the Glasgow Coma Scale (GCS) score of the patient at the time of the initial evaluation. ${ }^{[1]}$ The frequency of gunshot injuries to the head is on the increase and it becomes an important public health problem. Migration of the retained bullet is rare, and has been reported to occur in $0.06-4.2 \%$ of cases. ${ }^{[3,4]}$ Many cases of spontaneous migration have been reported in the brain and spinal canal..$^{[2,3,5-9]}$ Treatment of gunshot injuries is still debatable. The neurological status at the time of entry and location of the bullet often dictate the decision regarding surgical removal.

We report a case of spontaneous migration of a retained bullet by reviewing the relevant literature.

\section{CASE REPORT}

A 23-year-old male admitted with firearm injury to his head. In his physical examination, there was a single entry wound situated on the left side of the occipital bone, about $2 \mathrm{~cm}$ left of the midline and approximately $2.5 \mathrm{~cm}$ above the superior nuchal line; the exit wound could not be found. Brain tissue was 

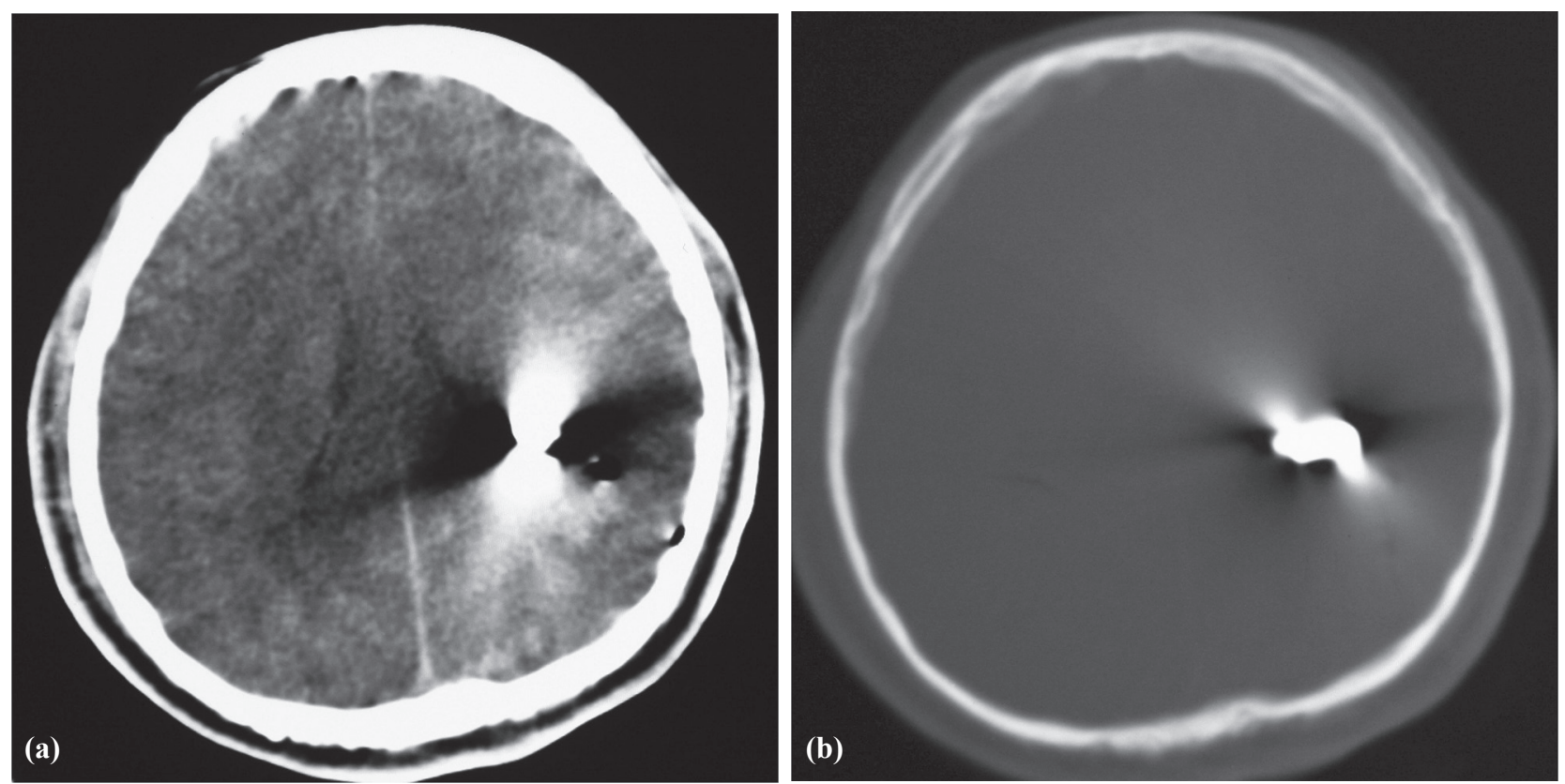

Fig. 1. (a) Initial CT showing deep-seated bullet in the left parietal region. (b) Initial CT scans using a bone algorithm. The bullet is located in the left parietal lobe.

seen through the open wound. In the first neurological examination, the patient was confused and GCS at the time of admission was 10 (E3V2M5). Pupils were equally reactive, and his vitals were stable. Cranial computerized tomography (CT) revealed a bone defect of $0.5 \mathrm{~cm}$ in the left occipital region and a metallic object located in the posterosuperior side of the left lateral ventricle's occipital horn. The bullet had passed through the left occipital lobe. There was hemorrhage along its trajectory, but the metal artifacts obscured the damage (Figs. 1a, b). The entry wound was debrided and sutured. The patient was treated conservatively with antibiotics, antiepileptics, and anti-edema drugs. Having recovered, repeated neurological examination revealed defect of the right visual fields of each eye (right homonymous hemianopsia). He was discharged from the hospital after seven days of observation. Two months later, repeat cranial CT demonstrated that the bullet was lying on the tentorium cerebelli near the midline in the posterior occipital region (Figs. 2a, b);
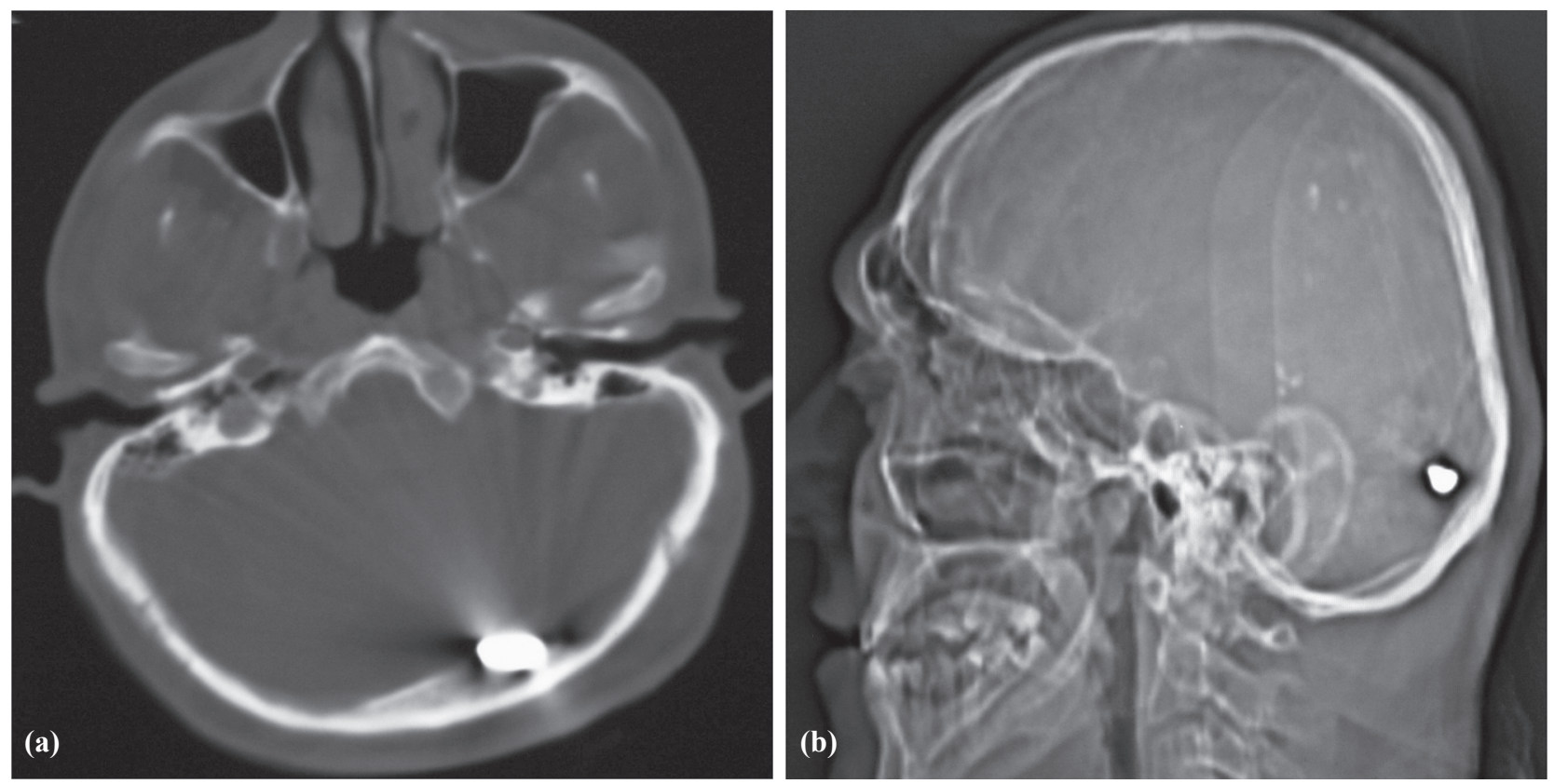

Fig. 2. (a) Axial CT scan after two months using a bone algorithm, demonstrating the new position of the bullet in the occipital region on the tentorium cerebelli. (b) Sagittal CT using a bone algorithm showing bullet migration to the occipital lobe on the tentorium cerebelli. 
when compared to the initial CT, it was observed that the bullet had migrated. Surgical intervention was not considered, as the patient displayed no new neurological deficit during the follow-up.

\section{DISCUSSION}

Migration of an intracranial bullet is a rare complication of gunshot injuries to the head. The time course for migration ranges from 2 days to 3 months. ${ }^{[2,7,10]}$ The course of a ricochet bullet is different from migration movement of a retained bullet. A ricochet bullet changes its direction after hitting the wall of the cranium or spinal canal, whereas retained bullet migration may be affected by several factors, such as gravitational factors. A bullet always tends to migrate. ${ }^{[9,11]}$

Various theories have been put forward regarding migration of the bullet. The movement of a bullet in the nervous system occurs mainly due to gravitational forces. ${ }^{[3]}$ Gravitational force acting on the bullet, which is denser than the surrounding medium, has been suggested as a cause for migration caudally by the effect of gravity related to the position of the body, especially in the absence of significant cranial swelling. ${ }^{[7,10]}$ Castillo-Rangel and Salvati ${ }^{[2,12]}$ suggested that the ventricular system provides transport of the bullet from one area of the brain to another. Cerebrospinal fluid (CSF) flow and pulsation will facilitate the bullet's movement within the ventricle. However, it is difficult to say whether or not the movement of the bullet in the brain parenchyma depends on brain pulsation. Bullets reaching the CSF may migrate to a distant part of the brain or the spinal canal through the CSF. Lang ${ }^{[2]}$ noted an intraventricular bullet had migrated to the aqueduct of Sylvius, producing acute hydrocephalus. Increased intracranial pressure due to cerebral swelling has been reported as a cause that prevents migration by compressing the pathway in the brain parenchyma. In the early stage after injury, brain edema may not allow migration of the bullet. However, migration along the CSF can still occur even in increased intracranial pressure. Penetration of the bullet leads to destruction in the white matter part of the parenchyma. This type of migration has been attributed to cerebral softening secondary to edema and local tissue damage, specific gravity of the bullet and gravitational factors. ${ }^{[2]}$ Bullets that cannot move within the brain after an initial movement are presumably walled off by gliosis and fibrotic scarring. These processes usually take from weeks to years. ${ }^{[2]}$ The deformed or non-deformed state of the bullet is significant; migration of a deformed bullet may be difficult due to increased resistance of the brain parenchyma. ${ }^{[6]}$ In our case, cranial CT taken two months after the injury revealed that the bullet had migrated towards the left posterior occipital lobe on the tentorium cerebelli when compared to the previous location, with caudal and posterior migration. In this case, movement of the intracranial bullet was ascribed to the specific gravity of the bullet, brain softening with loss of tissue resistance, white matter devitalization, and gravitational factors; however, gravity appears to be the most important factor responsible for the migration of the bullet. The petrous ridge, tentorium cerebelli and falx are natural barriers preventing migration of the bullet; ${ }^{[9]}$ therefore, we considered that the bullet could not migrate from the tentorium cerebelli to another part of the brain.

The indications for removal of an intracranial retained bullet are controversial and present a dilemma to the neurosurgeon. The management of these injuries needs to be studied in detail during the treatment procedure. Özkan and colleagues ${ }^{[9]}$ advised that a bullet in the brain should be removed if it can be reasonably accessed and if it can be removed without causing additional neurological damage. Kumar et al. ${ }^{[5]}$ reported that removal of the bullet should be done in patients undergoing surgery for evacuation of a hematoma if it is easily accessible and removal does not lead to further deterioration of the neurological status due to its proximity to vital structures. Fujimoto et al. ${ }^{[6]}$ stated that presence of a retained bullet and bone fragments do not increase the rate of intracranial infection; therefore, in an effort to prevent infection, removal of the bullet is not necessary. Zafonte et al. ${ }^{[13]}$ reported two cases with neurological deterioration from spontaneous migration of a bullet; postoperatively, the patients demonstrated significant functional recovery. The study of Fujimoto ${ }^{[6]}$ noted that a bullet within the ventricular system should be removed because hydrocephalus can be caused by obstruction of the foramen of Monro or aqueduct of Sylvius; however, a bullet within the brain parenchyma should be removed only when it can be easily accessed. Intracranial retained bullets require neurological observation and serial $\mathrm{CT}$ because migration may result in additional neurological deficits, and removal of the migrated bullet is thus advisable.

Surgery tends to achieve debridement of devitalized tissue, removal of bone fragments, hemostasis, dural closure, and suturation of the entrance and exit wounds. In addition, antiepileptic and anti-edema agents and antibiotics should be administered. It should be kept in mind that a retained bullet may cause potential complications, such as migration, abscess, ventriculitis, toxicity, epilepsy, and hydrocephalus, which warrant surgical intervention. However, removal of the bullet may cause iatrogenic damage to the brain parenchyma; therefore, if there is no evidence of infection or brain abscess formation or of additional neurological deficit during hospitalization, conservative management can be preferred. The decision of surgical treatment of a bullet injury is difficult if it is in close proximity to vital structures, since re- 
moval of the bullet may cause significant neurological damage; however, migration can lead to a worsening of the neurological status of the patient. Therefore, it was decided to treat the case conservatively since the bullet was close to optic radiation carrying visual information to the visual cortex and was also deepseated (in its first location). We assumed that the bullet on the tentorium cerebelli (second location) was fixed, and there was no new neurological deficit as a result of the bullet's migration. Preoperative localization of the bullet is important for its safe removal. CT taken shortly before surgery will be helpful for surgically accessing the bullet. Intraoperative fluoroscopy should also be performed to localize the bullet accurately. ${ }^{[6]}$ While plain X-rays are useful in demonstrating change in position, they are not sufficient for an accurate anatomical localization for the important operation.

In conclusion, if the bullet is close to vital structures, surgical intervention may not be considered. It is also recommended that deep-seated bullets be left, as any attempt at removal may increase the risk of morbidity and mortality; however, it should be kept in mind that the migrated bullet may also cause damage to a vital structure, leading to significant neurological damage.

\section{REFERENCES}

1. Ozdemir M, Unlü A. Gunshot injuries due to celebratory gun shootings. Turk Neurosurg 2009;19:73-6.

2. Castillo-Rangel C, Reyes-Soto G, Mendizábal-Guerra R. Cranio-thoracic bullet migration over a period of 27 years: case report. Neurocirugia (Astur) 2010;21:326-9.

3. Farrugia A, Raul JS, Géraut A, Ludes B. Ricochet of a bullet in the spinal canal: a case report and review of the literature on bullet migration. J Forensic Sci 2010;55:1371-4.

4. Rapp LG, Arce CA, McKenzie R, Darmody WR, Guyot DR, Michael DB. Incidence of intracranial bullet fragment migration. Neurol Res 1999;21:475-80.

5. Kumar R, Garg P, Maurya V, Sahu RN, Mahapatra AK. Spontaneous bullet migration-uncommon sequelae of firearm injury to the brain. Ind J Neurotrauma 2008;5:119-21.

6. Fujimoto Y, Cabrera HT, Pahl FH, de Andrade AF, Marino JR. Spontaneous migration of a bullet in the cerebellum-case report. Neurol Med Chir (Tokyo) 2001;41:499-501.

7. Agrawal A, Pratap A, Rauniar RK, Kumar A, Nepal U. Intracranial ricocheting of bullet from anterior clinoid process. JNMA J Nepal Med Assoc 2008;47:145-6.

8. Young WF Jr, Katz MR, Rosenwasser RH. Spontaneous migration of an intracranial bullet into the cervical canal. South Med J 1993;86:557-9.

9. Ozkan U, Ozateş M, Kemaloğlu S, Güzel A. Spontaneous migration of a bullet into the brain. Clin Neurol Neurosurg 2006;108:573-5.

10. Arasil E, Taşçioğlu AO. Spontaneous migration of an intracranial bullet to the cervical spinal canal causing Lhermitte's sign. Case report. J Neurosurg 1982;56:158-9.

11. Duman H, Ziyal IM, Canpolat A. Spontaneous subfalcial transcallosal migration of a missile to the contralateral hemisphere causing deterioration in neurological status-case report. Neurol Med Chir (Tokyo) 2002;42:332-3.

12. Salvati M, Cervoni L, Rocchi G, Rastelli E, Delfini R. Spontaneous movement of metallic foreign bodies. Case report. J Neurosurg Sci 1997;41:423-5.

13.Zafonte RD, Watanabe T, Mann NR. Moving bullet syndrome: a complication of penetrating head injury. Arch Phys Med Rehabil 1998;79:1469-72. 